\title{
Epicormic sprout development in pruned coast redwood: pruning severity, genotype, and sprouting characteristics
}

\author{
Kevin L. O'HARA ${ }^{1 *}$, John-Pascal BERRILL ${ }^{2}$ \\ ${ }^{1} 137$ Mulford Hall, Department of Environmental Science, Policy and Management, University of California, Berkeley, CA 94720-3114, USA \\ ${ }^{2}$ Department of Forestry \& Wildland Resources, Humboldt State University, One Harpst Street, Arcata, CA 95521, USA
}

(Received 25 February 2008; revised version 11 September 2008; accepted 26 November 2008)

Keywords:

Sequoia sempervirens / artificial pruning /

epicormic sprouts /

stand management

\begin{abstract}
- Young coast redwood (Sequoia sempervirens (D. Don.) Endl.) trees were pruned to various heights to examine the effect of pruning severity on epicormic sprouting. Seven separate stands were used with as many as six treatments per stand in coastal Humboldt County, California, USA.

- Epicormic sprout development was affected by pruning severity but primarily at the most severe pruning treatments that removed all but the branches in the top $15 \%$ of tree height. Less severe treatments produced sprouts but the number and size of these sprouts were comparable to unpruned trees.

- Natural clonal patterns were also used to explore patterns of sprouting between genotypes. Linear mixed-effects models were developed to predict sprouting frequency as a function of pruning severity while accounting for the nested data structure (i.e., stem sections sampled nested within genotypes within treatments within sites).

- Comparing variances attributed to each of these random effects indicated that at any level of pruning severity, differences in epicormic sprouting between genotypes and sites expressed soon after pruning had disappeared after six growing seasons. Epicormic branches were more common two years after pruning than six years indicating many branches were dying. Branches were more common in the middle of the pruned bole, possibly because of competition from basal sprouts and the expanding tree crown.
\end{abstract}

Résumé - Développement de rejets épicormiques sur des séquoias californiens : intensité de l'élagage, génotype, caractéristiques des rejets.

- De jeunes séquoias de Californie (Sequoia sempervirens (D. Don.) Endl.) ont été élagués à différentes hauteurs afin d'examiner l'effet de l'intensité de l'élagage sur les rejets épicormiques. Sept peuplements ont été utilisés avec jusqu'à six traitements par peuplement dans la région côtière du Comté de Humboldt en Californie (USA).

- Le développement des rejets épicormiques a été affecté par l'intensité de l'élagage, mais surtout par les traitements les plus sévères qui ont presque supprimé toutes les branches au sommet sur $15 \%$ de la hauteur des arbres. Des traitements moins sévères ont produit des rejets, mais le nombre et la dimension de ces rejets étaient comparables à ceux des arbres non élagués.

- Des clones naturels ont également été utilisés pour explorer les modèles de rejet entre génotypes. Des modèles linéaires a effets mixtes ont été développés pour prédire la fréquence des rejets en fonction de l'intensité de l'élagage, en prenant en compte la structure imbriquée des données (c'est-à-dire, les sections du tronc échantillonnées, imbriquées avec les génotypes, les traitements et les stations). - La comparaison des variances attribuées à chacun de ces effets aléatoires a indiqué qu'à tout niveau d'intensité d'élagage, les différences de rejets épicormiques entre les génotypes et les stations exprimées peu de temps après la taille avaient disparu au bout de six saisons de croissance.

- Les branches épicormiques ont été plus fréquentes deux ans après l'élagage que six ans plus tard indiquant que de nombreuses branches sont en train de mourir. Les branches ont été plus fréquentes dans le milieu de la partie du tronc élaguée, peut-être en raison de la concurrence des rejets de la base et de l'expansion du houppier.

\footnotetext{
* Corresponding author: ohara@ nature.berkeley.edu
} 


\section{INTRODUCTION}

Coast redwood (Sequoia sempervirens (D. Don.) Endl.) is noted for its rapid growth rates, the large sizes attained by individual trees, its longevity, and the durability of its wood. It is also unique among conifers because of its sprouting potential. Redwood commonly regenerates through stump sprouts after cutting or fire. It is also capable of reproducing through basal sprouts or root sprouts from uncut trees, layering, or even from sprouts along the length of down logs. Epicormic sprouts are commonly produced after increased bole exposure including after artificial pruning. These sprouts originate from a lignotuber near the base (Del Tredici, 1998), or dormant (preventitious, Fink, 1984) and adventitious buds on the tree bole, and are generally assumed to be an adaptation to allow rapid replacement of lost foliage.

Redwood's tendency to reproduce through stump sprouts after timber harvest results in aggregated spatial patterns of individual trees with aggregated distributions of clones (Douhovnikoff et al., 2004). Old trees commonly had diameters of several meters and second-growth trees may have approached a meter or more in diameter depending on harvest age. The horizontal spread of a single clone over just three generations may therefore be quite large since sprouts commonly occur on all sides of a stump. For example, Douhovnikoff et al. (2004) found clones in second-growth stands extending as far as $40 \mathrm{~m}$.

Reforestation in managed redwood stands following timber harvest is primarily through stump sprouts with some supplemental planting of redwood or coast Douglas-fir to fill unstocked openings. Because of redwood's resistance to decay, the original stumps are usually still present many decades after harvest. As a result, cross-generational clonal patterns of redwood sprouts are apparent in these stands and clonal patterns can be determined with a high degree of certainty because of the proximity and physical relationship of sprouts to cut stumps.

Epicormic sprout production is a common result of artificial pruning in some conifers such as coast Douglas-fir (Pseudotsuga menziesii var. menziesii (Mirb.) Franco; Collier and Turnblom, 2001; Eckstein, 1974), Sitka spruce (Picea sitchensis (Bong.) Carr.; Deal et al., 2003), radiata pine (Pinus radiata D. Don; Hingston, 1990; Lange et al., 1987), western larch (Larix occidentalis L.; O'Hara and Valappil, 2000; Waring and O'Hara, 2005), giant sequoia (Sequoiadendron giganteum (Lindl.) Buchh.; O'Hara et al., 2008), true firs (Abies species; Cosens, 1952), as well as many broadleaf species (Evans, 1987; Kerr and Harmer, 2001). Epicormic sprouts in the pruned section of the tree bole form wood quality defects that extend into wood formed after pruning. These sprouts produce knots and degrade lumber value and both the number and size of sprouts affect wood quality.

It has been suggested that epicormic sprouts develop in reaction to reduced photosynthetic area or increased bole exposure (Büsgen and Münch, 1929; Kozlowski and Pallardy, 1997; Zimmermann and Brown, 1971). For some species, the rapid increase in leaf area with the production of epicormic sprouts can help regain photosynthetic area or help mitigate the cost of inefficient older branches with new small branches (Bégin and Filion, 1999; Ishii and Ford, 2001; Ishii et al., 2002). For pruned trees, pruning severity was cited as a primary cause of epicormic sprout development in many studies with greater severity leading to increased sprouting and greater persistence of sprouts (Deal et al., 2003; O'Hara et al., 2008; Waring and O'Hara, 2005). Several of these studies found that sprouts appear soon after pruning but tend to decline over time (O'Hara et al., 2008; Stein, 1955; Waring and O'Hara, 2005). Other studies reported greater sprouting on the exposed sides of tree boles after artificial pruning (Collier and Turnblom, 2001; Deal et al., 2003; O'Hara et al., 2008), suggesting light or heat may be causal factors. It has also been speculated that some trees are more genetically prone to develop epicormic sprouts (Evans, 1987) although this has not been tested.

Genetics and tree breeding experiments could be used to quantify the heritability of epicormic sprouting. Unfortunately, testing pruning severity in such experiments would either confound assessments of other traits such as growth, form, and health, or require a larger experiment to compensate for variability introduced by different pruning treatments. Natural clonal patterns in stands regenerated by stump sprouts could also be used to test for genetic effects on epicormic sprouting. In this case, the analysis is complicated because observations (i.e., stump sprout trees) are not independent. Mixedeffects analysis techniques offer a solution to this problem by allowing fixed effects such as pruning treatment and random effects such as genotype to enter models of epicormic sprouting (Littell et al., 2006).

The easily-distinguished clonal patterns of redwood sprouts in young stands present the opportunity to examine the contribution of tree genotype to development of epicormic branches. However, no previous study has examined the effect of pruning severity on epicormic sprout production in redwood. This study therefore sought to examine and model the effects of pruning severity using data from a series of pruning trials in young redwood stands exhibiting natural clonal patterns. The objectives of this analysis were to assess the effect of pruning severity on epicormic sprout development and then to examine the importance of genotype in affecting sprout development. Patterns of sprout persistence and position on the stem are also presented.

\section{MATERIALS AND METHODS}

\subsection{Study areas}

Seven study areas were established in the winter of 1999-2000 in recently pruned, precommercially thinned, young redwood stands in Humboldt County California (Tab. I). Study areas were in highly productive, intensively managed redwood stands within approximately $20 \mathrm{~km}$ of the California coast and ranged in latitude from approximately 40.54 to $41.03^{\circ} \mathrm{N}$. All stands were even-aged resulting from clearcuts approximately $5-15$ y prior to initiation of this study. Stands were regenerated by stump sprouts and some interplanting of redwood or coast Douglas-fir in openings. The objective of pruning treatments was primarily to assess the effect of pruning intensity on growth and epicormic sprouting but also on stem taper and wood 
Table I. Coast redwood pruning treatments, pruning heights, residual crown lengths, diameters, stand ages, and dates of precommercial thinning by study area and treatment at the time of pruning (winter of 1999-2000). Actual average residual crown lengths show the average of actual crown lengths of control trees or pruned trees after pruning.

\begin{tabular}{|c|c|c|c|c|c|c|}
\hline Study areas & $\begin{array}{l}\text { Treatment } \\
\text { prescription* }\end{array}$ & $\begin{array}{l}\text { Mean tree height } \\
\text { in 1999-2000 (m) }\end{array}$ & $\begin{array}{l}\text { Actual average residual } \\
\text { crown length }(\%)\end{array}$ & $\begin{array}{c}\text { Mean dbh in } \\
1999-2000(\mathrm{~cm})\end{array}$ & $\begin{array}{c}\text { Stand age in } \\
1999-2000(\mathrm{y})\end{array}$ & PCT date \\
\hline \multirow[t]{6}{*}{299 Cutoff } & Control & 9.6 & 71 & 14.2 & 5 & 1999 \\
\hline & $60 \%$ & 9.4 & 56 & 12.3 & 5 & 1999 \\
\hline & $45 \%$ & 10.4 & 46 & 13.9 & 5 & 1999 \\
\hline & $5.5 \mathrm{~m}$ or $35 \%$ & 9.6 & 47 & 14.2 & 5 & 1999 \\
\hline & $30 \%$ & 9.0 & 35 & 12.0 & 5 & 1999 \\
\hline & $15 \%$ & 9.7 & 24 & 14.5 & 5 & 1999 \\
\hline \multirow[t]{5}{*}{ M-line } & Control & 7.4 & 80 & 9.9 & 7 & 1999 \\
\hline & $60 \%$ & 6.0 & 57 & 7.6 & 7 & 1999 \\
\hline & $45 \%$ & 7.6 & 42 & 11.3 & 7 & 1999 \\
\hline & $30 \%$ & 8.3 & 39 & 11.8 & 7 & 1999 \\
\hline & $15 \%$ & 6.8 & 22 & 9.7 & 7 & 1999 \\
\hline \multirow[t]{2}{*}{ Maple Creek } & Control & 9.7 & 78 & 13.2 & 11 & 1998 \\
\hline & $4.9-5.5 \mathrm{~m}$ & 10.8 & 53 & 17.2 & 11 & 1998 \\
\hline \multirow[t]{2}{*}{ Fortuna } & Control & 12.5 & - & 21.1 & 14 & 1997 \\
\hline & $3.0-5.5 \mathrm{~m}, 40 \%$ & 11.9 & 54 & 24.6 & 14 & 1997 \\
\hline \multirow[t]{4}{*}{ Carlotta } & Control & 10.7 & 67 & 14.5 & 8 & 1999 \\
\hline & $2.4 \mathrm{~m}$ & 10.4 & 65 & 16.0 & 8 & 1999 \\
\hline & $3.0-5.5 \mathrm{~m}, 40 \%$ & 10.2 & 49 & 14.9 & 8 & 1999 \\
\hline & $3.0-5.5 \mathrm{~m}, 40 \%$ & 11.6 & 46 & 18.6 & 8 & 1999 \\
\hline \multirow[t]{4}{*}{ M-150 } & Control & 10.2 & 80 & 13.4 & 7 & 1999 \\
\hline & Control & 10.1 & 78 & 12.1 & 7 & 1999 \\
\hline & $2.4 \mathrm{~m}$ & 10.4 & 72 & 13.8 & 7 & 1999 \\
\hline & $3.0-5.5 \mathrm{~m}, 40 \%$ & 8.9 & 43 & 12.3 & 7 & 1999 \\
\hline \multirow[t]{3}{*}{ Mitsui } & Control & 7.6 & 81 & 11.2 & 7 & 1999 \\
\hline & $2.4 \mathrm{~m}$ & 7.2 & 67 & 10.2 & 7 & 1999 \\
\hline & $3.0-5.5 \mathrm{~m}, 40 \%$ & 7.4 & 49 & 13.2 & 7 & 1999 \\
\hline
\end{tabular}

* Unpruned control, targeted pruned height $(\mathrm{m})$, or residual crown length in percent of total height $(\%)$.

$\mathrm{PCT}=$ precommercial thinning. If the precommercial thinning date was 1999 then it was done simultaneously with pruning.

quality. Five of the pruned study areas received operational pruning treatments where one or two levels of pruning intensity were used. In these areas, pruning was to a pre-specified height of selected trees based on bole form. In the other two study areas, five or six pruning treatments were used to determine a range of responses. In these areas (299 Cutoff and M-line), treatments were generally to a prespecified post-pruning live crown percent (Tab. I). All study areas included unpruned controls that were either separate treatment areas or unpruned trees within the pruned treatment areas. M-150 had two separate control areas that were treated as separate plots in the study. Pruning occurred shortly before establishment of pruning study areas in the winter of 1999-2000. Precommercial thinning was performed prior to, or in conjunction with, the pruning treatments (Tab. I) and typically left 800 to 900 trees $^{\prime} \mathrm{ha}^{-1}$.

Stands receiving pruning treatments were variable in size depending on the pruning/thinning regime, stand size, and resources available for pruning. In some stands several hectares were pruned, in other stands pruning was limited to the study area. Sampling was based on individual trees within treated areas rather than fixed-area plots and treated areas are referred to as "study areas". Approximately 30 trees were tagged and measured in each study area after pruning. Tree selection criteria was based on trees meeting treatment specifications (pruning height) and being free of stem form defects. Trees generally had full crowns at the time of pruning at all treatment areas. Pruning was completed with chainsaws and using cuts that were close to the stem (O'Hara, 2007).

\subsection{Measurements}

Initial tree measurements included tree height, height to the crown base before and after pruning, and dbh. As "third-growth" redwood stands, these redwood trees were second-generation stump sprouts from the original timber harvest. Trees from common stumps (first and second generation) were therefore generally apparent and were noted.

In 2002, or two growing seasons after treatment, boles of pruned trees were sampled for epicormic sprouts. A random selection of ten trees per treatment within each study area was used. However, some treatments had slightly more trees. The pruned lengths of the boles were divided into six equal sections and a random section was selected for measurement and marked with paint. A tree pruned to $3.0 \mathrm{~m}$ therefore had one $0.5 \mathrm{~m}$ bole section randomly selected for measurement from the pruned $3.0 \mathrm{~m}$ bole. On this section, all epicormic sprouts were counted and the uppermost and lowermost sprouts were measured for length and diameter at branch base. These two sprout positions were selected as an unbiased and random sample of sprout size without the effects of vertical position on the bole. Trees in control study areas (precommercially thinned, but not pruned) were randomly selected and measured in similar ways to determine effects of precommercial thinning on sprouting. A height equal to the greatest pruned height in adjacent pruned treatments was used as the basis for dividing the bole into six equal sections in these control trees. Sprouts were counted and measured on control trees using only 
sprouts believed to have originated after the pruning in adjacent treatment areas.

In 2006, or six growing seasons after treatment, the same bole sections were relocated and remeasured for number of sprouts, and the length and caliper of the lowermost and uppermost sprout. Because of sprout emergence and mortality between 2002 and 2006, different sprouts may have been measured at these two dates. By 2002 and particularly by 2006 , many trees were damaged by bears and a few others were lost to stem breakage/windthrow. These trees were not included in this analysis.

\subsection{Analysis}

Numbers of epicormic sprouts per bole-section were expanded from bole-section to number of sprouts per tree and averaged by treatment area. Analysis of variance or $t$-tests were used to compare means for number of sprouts/tree between treatments within study areas. Similar analysis procedures were used on epicormic branch length and branch caliper data. Tukey's HSD was used to identify significantly different means. Numbers of sprouts were also expressed per meter of pruned bole and assessed using post-pruning crown length as a continuous variable for all pruned trees. Post-pruning crown length was the difference between initial tree height at time of pruning and pruning height. Percent live crown was crown ratio presented as a percentage, where crown ratio was post-pruning crown length divided by initial tree height, and was used to characterize pruning severity.

Bole section counts of epicormic sprouts were also combined across all study sites for comparisons of sprouting by height for pruned trees. Numbers of sprouts per $m$ in both 2002 and 2006 were compared by bole section. Because many sprout counts were zero, comparisons used the non-parametric Kruskal-Wallis rank tests using bole section as a categorical variable. Presence of sprouts was compared by bole section from 2002 to 2006 and tested with Wilcoxon sum rank tests.

Mixed effects models were constructed to predict number of sprouts present in 2002 and 2006 as a function of pruning severity. Linear mixed effects models accounted for different sources of variation within the nested data structure i.e., bole section sampled within clones within treatments within study sites, by incorporating random effects for each tier. Variances associated with each random effect were compared, indicating relative importance of each source of variation e.g., comparing differences between sites versus differences between genotypes (Crawley, 2002). Crown ratio, the independent variable representing pruning severity, entered the mixed models as a fixed effect. Logarithmic transformation reduced skewness in sprout number data distributions. Data were analyzed using S-Plus statistical analysis software with linear mixed effects models fit using lme procedure with restricted maximum likelihood (REML) (Insightful Corp., 2005).

\section{RESULTS}

\subsection{Sprout frequency and size}

The severity of pruning affected the average number of sprouts per tree on most study areas that included multiple pruning treatments. However, there was considerable variation in number of sprouts for a given percent live crown up to 60 percent live crown (Fig. 1). At the M-line study area, the 15\%

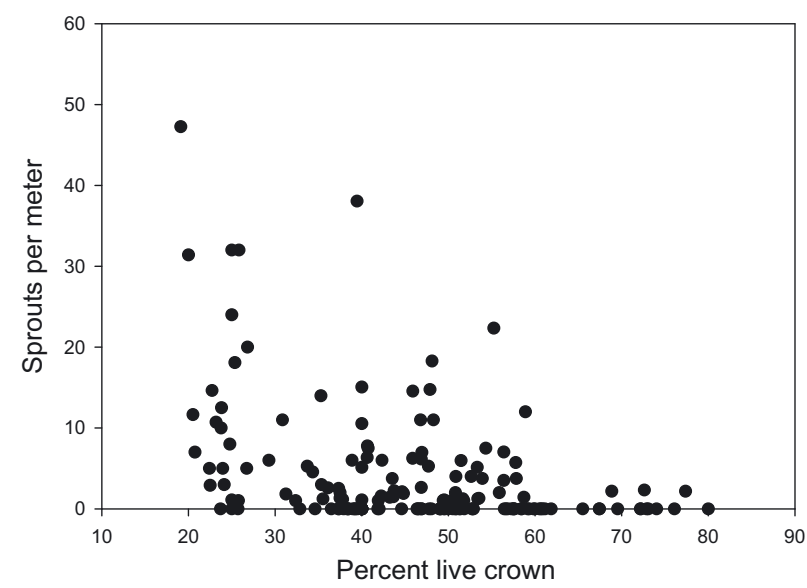

Figure 1. Sprouts per meter of pruned bole and percent live crown immediately after pruning in 1999-2000 for pruned coast redwood trees.

live crown treatment averaged 342.7 sprouts/tree in 2002 and 169.0 sprouts/tree in 2006 (Tab. II). Otherwise, there were no significant differences in sprouts/tree at M-line. The 299 Cutoff site experienced similar trends with treatment but without any significant differences by 2006. Both the Carlotta and M150 sites also had significant differences between controls and pruned treatments in 2002 but not in 2006.

The size of sprouts was also affected by pruning severity. Generally sprout length and branch diameter in 2002 and 2006 were greater following more severe pruning but these differences were seldom significant (Tab. III). Sample sizes for sprout length and branch diameter at base were limited to no more than two sprouts per tree that experienced sprouting: small sample sizes therefore reduced the ability to detect significant differences in sprout size between treatments. Control trees generally had the smallest sprouts. Average branch diameter exceeded $1.0 \mathrm{~cm}$ at the 299 Cutoff site in the most severe treatment or approximately an order of magnitude greater than in the control trees.

\subsection{Sprout persistence and position on bole}

Epicormic sprout development was a common occurrence on all study areas including the controls. In 2002, 75.4 percent of pruned trees had at least one sprout. By 2006 this percentage had dropped to 55.1 for pruned trees. Control trees also had epicormic sprouts that formed after 1999-2000: $45.3 \%$ of trees had sprouts in 2002 compared to $29.4 \%$ in 2006 . By 2006 , $70.7 \%$ of trees had a reduction in numbers of sprouts from 2002 and 25.7 percent had remained unchanged. Only 3.6\% of trees had an increase in sprouts between 2002 and 2006.

Sprouts per meter of pruned bole length were not equally distributed along the bole of pruned trees (Fig. 2), however, differences in the non-parametric Kruskal-Wallis rank test for number of sprouts per section were not significant in either $2002(p=0.075)$ or $2006(p=0.137)$. Sprouts were concentrated in the middle and top sections of the pruned boles 
Table II. Redwood epicormic sprout data for pruned and unpruned study areas in 2002 and 2006. Several treatments at Fortuna, Carlotta or Mitsui were not measured for epicormic sprouts because of extensive bear damage. Common lower case letters within study sites denote means that were not significantly different. Standard errors (SE) are given in parentheses following means. Samples sizes are number of trees.

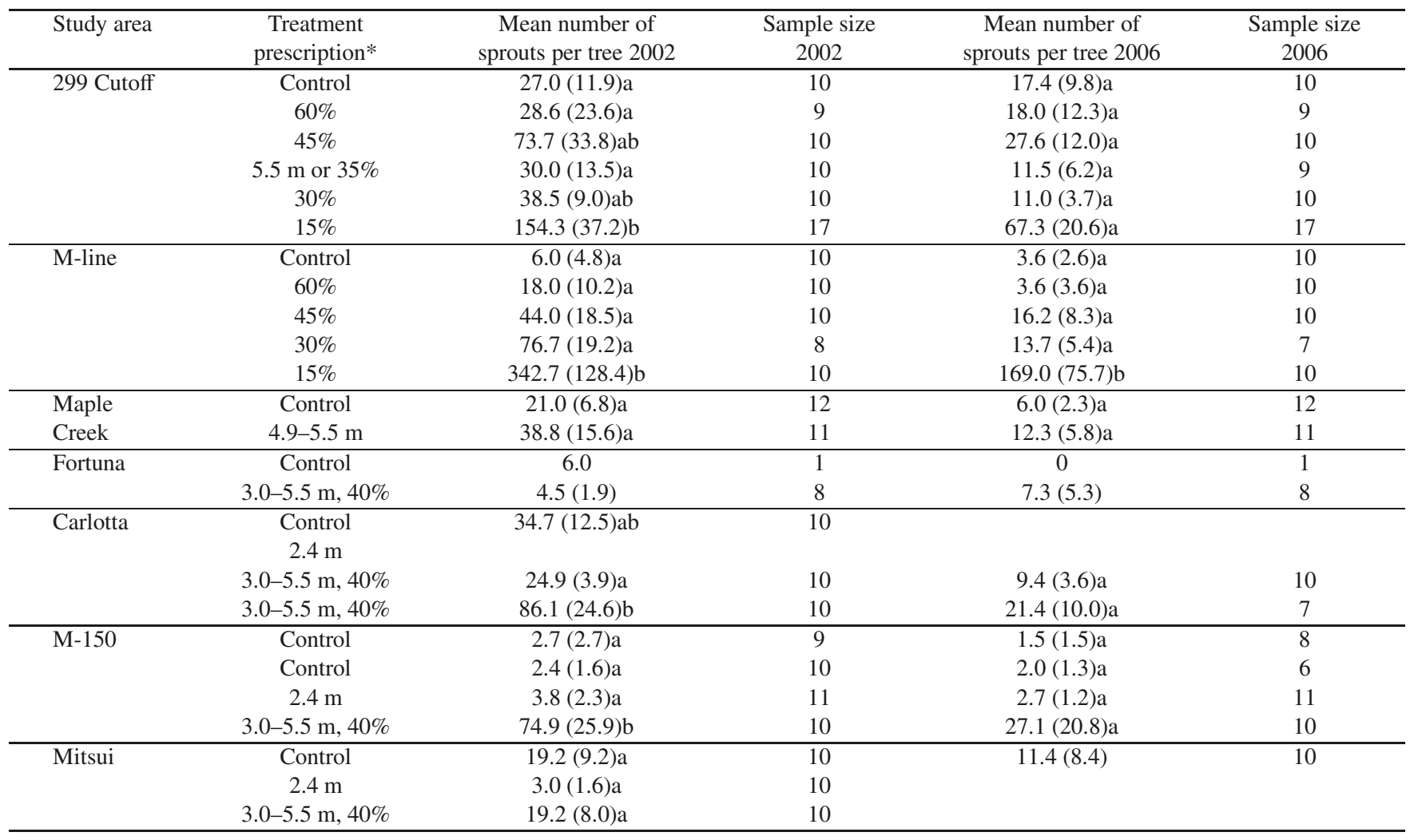

* Unpruned control, targeted pruned height $(\mathrm{m})$, or residual crown length in percent of total height $(\%)$.

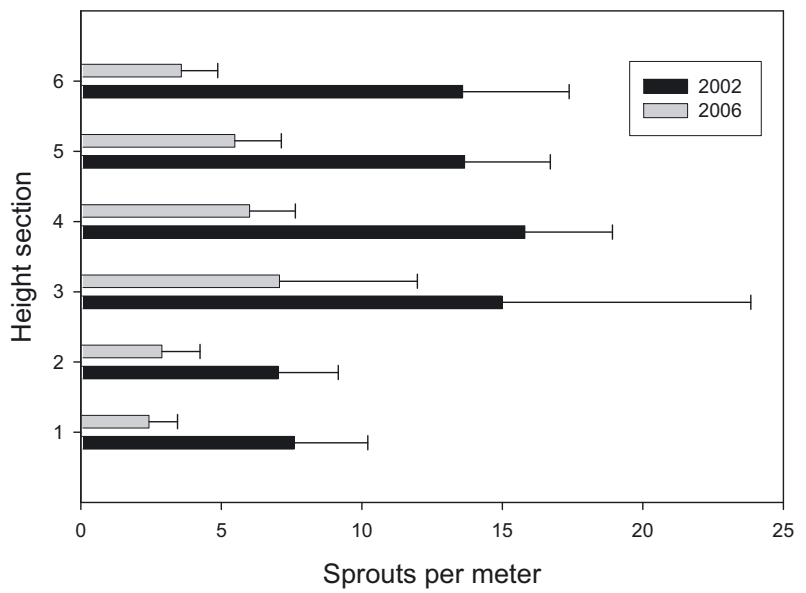

Figure 2. Number of sprouts per meter of pruned bole by height section (e.g., Section 1 was lowest 1/6th of pruned bole) for pruned redwood trees. Shown are means plus standard errors. Sample sizes ranged from 19 to 35 per height section.

and less common at the bottom. All height sections experienced reduced numbers of sprouts in 2006 compared to 2002.

\subsection{Modeling effects of pruning severity}

The number of sprouts per meter of stem on pruned trees was highly variable, ranging from zero to 74 (and one extreme value of 258) in 2002, and zero to 47 (and one extreme value of 143) in 2006. Table IV contains model coefficients and fit statistics for linear mixed-effects models of the natural logarithm of number of sprouts per meter of pruned stem $(N)$ as a function of crown ratio immediately after pruning (CR), with random intercept terms for site, treatments, clone, and bole section sampled. Comparing models for 2002 and 2006 indicated that more severe pruning induced prolific epicormic sprouting, but that many of these sprouts did not persist to 2006 (Fig. 3). Comparing actual and predicted number of sprouts per meter for all pruned trees showed that an average prediction error (RMSE) of \pm 22.6 and 13.2 sprouts per meter of pruned stem could be expected for predictions two and six years after pruning, respectively (Tab. IV).

Mixed model variances showed that variability in epicormic sprouting was observed at different heights along the pruned stem, between study sites, and between genotypes. Differences in sprouting between the six different sections of pruned bole sampled represented the largest source of 'random-effects' variation within the nested data structure; variations in sprouting between stem sections almost equaled the model residual 
Table III. Redwood epicormic sprout length and caliper for pruned and unpruned study areas in 2002 and 2006. Several treatments at Fortuna, Carlotta or Mitsui were not measured for epicormic sprouts because of extensive bear damage. Means followed by common letters within a study area were not significantly different $(\alpha=0.05)$. Sample sizes are number of sprouts.

\begin{tabular}{|c|c|c|c|c|c|c|c|}
\hline Study area & $\begin{array}{c}\text { Treatment } \\
\text { prescription* }\end{array}$ & $\begin{array}{l}\text { Mean sprout length } \\
\text { at base } 2002(\mathrm{~cm})\end{array}$ & $\begin{array}{l}\text { Mean sprout length } \\
\text { at base } 2006(\mathrm{~cm})\end{array}$ & $\begin{array}{c}\text { Mean sprout diameter } \\
2002(\mathrm{~cm})\end{array}$ & $\begin{array}{c}\text { Mean sprout diameter } \\
2006(\mathrm{~cm})\end{array}$ & $\begin{array}{l}\text { Sample size } \\
2002\end{array}$ & $\begin{array}{l}\text { Sample size } \\
2006\end{array}$ \\
\hline \multirow[t]{6}{*}{299 Cutoff } & Control & $2.5 \mathrm{a}$ & $2.7 \mathrm{a}$ & $0.13 \mathrm{a}$ & $0.11 \mathrm{a}$ & 9 & 3 \\
\hline & $60 \%$ & $4.9 \mathrm{a}$ & $6.4 \mathrm{a}$ & $0.13 \mathrm{a}$ & $0.19 a$ & 7 & 5 \\
\hline & $45 \%$ & $7.2 \mathrm{a}$ & $11.3 \mathrm{a}$ & $0.17 \mathrm{a}$ & $0.20 \mathrm{a}$ & 15 & 7 \\
\hline & $5.5 \mathrm{~m}$ or $35 \%$ & $7.7 \mathrm{a}$ & $16.7 \mathrm{a}$ & $0.20 \mathrm{a}$ & $0.25 \mathrm{a}$ & 15 & 4 \\
\hline & $30 \%$ & $15.4 \mathrm{a}$ & $23.8 \mathrm{a}$ & $0.29 \mathrm{a}$ & $0.40 \mathrm{ab}$ & 18 & 7 \\
\hline & $15 \%$ & $54.8 \mathrm{~b}$ & $115.4 \mathrm{~b}$ & $0.78 b$ & $1.04 \mathrm{~b}$ & 34 & 14 \\
\hline \multirow[t]{5}{*}{ M-line } & Control & $0.6 \mathrm{a}$ & $1.6 \mathrm{a}$ & $0.16 \mathrm{a}$ & $0.15 a$ & 4 & 2 \\
\hline & $60 \%$ & $3.0 \mathrm{a}$ & $1.4 \mathrm{a}$ & $0.17 \mathrm{a}$ & $0.18 \mathrm{a}$ & 8 & 1 \\
\hline & $45 \%$ & $16.2 \mathrm{ab}$ & $61.7 \mathrm{a}$ & $0.26 \mathrm{a}$ & $0.63 a$ & 14 & 3 \\
\hline & $30 \%$ & $16.7 \mathrm{ab}$ & $86.6 \mathrm{a}$ & $0.30 \mathrm{ab}$ & $0.85 a$ & 16 & 6 \\
\hline & $15 \%$ & $55.6 \mathrm{~b}$ & $73.6 \mathrm{a}$ & $0.68 \mathrm{~b}$ & $0.74 a$ & 20 & 10 \\
\hline \multirow[t]{2}{*}{ Maple Creek } & Control & $2.4 \mathrm{a}$ & $1.9 \mathrm{a}$ & $0.13 a$ & $0.18 \mathrm{a}$ & 15 & 6 \\
\hline & $4.9-5.5 \mathrm{~m}$ & $3.4 \mathrm{a}$ & $1.9 \mathrm{a}$ & $0.14 \mathrm{a}$ & $0.16 \mathrm{a}$ & 14 & 6 \\
\hline \multirow[t]{2}{*}{ Fortuna } & Control & & & & & & \\
\hline & $3.0-5.5 \mathrm{~m}, 40 \%$ & 2.6 & 2.5 & 0.15 & 0.20 & 5 & 3 \\
\hline \multirow[t]{3}{*}{ Carlotta } & $\begin{array}{c}\text { Control } \\
2.4 \mathrm{~m}\end{array}$ & $2.0 \mathrm{a}$ & & $0.15 a$ & & 15 & \\
\hline & $10-18 \mathrm{ft}, 40 \%$ & $3.6 \mathrm{a}$ & $5.4 \mathrm{a}$ & $0.16 \mathrm{a}$ & $0.28 \mathrm{a}$ & 19 & 6 \\
\hline & $10-18 \mathrm{ft}, 40 \%$ & $2.3 \mathrm{a}$ & $36.1 \mathrm{a}$ & $0.14 \mathrm{a}$ & $0.48 \mathrm{a}$ & 18 & 4 \\
\hline \multirow[t]{4}{*}{ M-150 } & Control & $1.3 \mathrm{a}$ & $3.8 \mathrm{a}$ & 0.13 & $0.17 \mathrm{a}$ & 2 & 1 \\
\hline & Control & $1.3 \mathrm{a}$ & $17.5 \mathrm{a}$ & $0.18 \mathrm{a}$ & $0.58 \mathrm{a}$ & 4 & 2 \\
\hline & $8 \mathrm{ft}$ & $0.9 \mathrm{a}$ & $1.3 \mathrm{a}$ & $0.10 \mathrm{a}$ & $0.15 a$ & 5 & 4 \\
\hline & $10-18 \mathrm{ft}, 40 \%$ & $8.9 \mathrm{a}$ & $17.6 \mathrm{a}$ & $0.20 \mathrm{a}$ & $0.38 \mathrm{a}$ & 18 & 5 \\
\hline \multirow[t]{3}{*}{ Mitsui } & Control & $2.9 \mathrm{a}$ & 2.8 & $0.14 a$ & 0.19 & 8 & 3 \\
\hline & $8 \mathrm{ft}$ & $19.8 \mathrm{a}$ & & $0.28 \mathrm{a}$ & & 5 & \\
\hline & $10-18 \mathrm{ft}, 40 \%$ & $16.3 \mathrm{a}$ & & $0.21 \mathrm{a}$ & & 12 & \\
\hline
\end{tabular}

* Unpruned control, targeted pruned height (m), or residual crown length in percent of total height (\%).

variance - the amount of unexplained variation in sprouting - in 2002 and still represented an important source of variation six years after pruning in 2006. Random effects variances attributed to differences between study sites were relatively large in 2002, but were virtually non-existent in 2006. Similarly, the number of sprouts per meter of pruned stem varied widely between genotypes in 2002, but varied much less in 2006 (Tab. IV).

\section{DISCUSSION}

\subsection{Pruning and epicormic sprouting}

The development of epicormic sprouts in conifers after pruning is complicated by several important and interacting processes. The principle stimuli are generally assumed to be the combined effects of a reduced photosynthetic capacity (i.e., loss of foliage) and greater exposure to light or heat. Several studies report increasing sprout production with increasing pruning severity (Collier and Turnblom, 2001; Eckstein, 1974; O'Hara et al., 2008; Stein, 1955; Waring and O'Hara, 2005) and greater sprout numbers/sizes on the exposed sides of tree boles (Collier and Turnblom, 2001; Deal et al., 2003;
O'Hara et al., 2008). These are evolutionary adaptions that allow trees to quickly rebuild crowns after disturbances such as defoliations and branch damage (Begin and Filion, 1999; Ishii and Ford, 2001; Ishii et al., 2002). In contrast to crown disturbances such as fire, wind, or ice damage, typical forest pruning provides a much more uniform reduction in lower crowns and causes relatively uniform sprout reactions in susceptible species. As crowns rebuild following pruning, epicormic branches on the lower stem become less important sources of photosynthates because the tree is increasing in height and expanding crown upward and outward. Sprouts therefore become more shaded and often disappear with time since pruning as the tree increases in height and the crown expands (Auchmoody, 1972; O'Hara et al., 2008; Stein, 1955; Waring and O'Hara, 2005). Although seasonal effects have been reported for sprouting following cutting of tree stems (Harrington, 1984), similar effects of epicormic sprouting in pruned giant sequoia were transient (O’Hara et al., 2008).

Coast redwood closely follows this conceptual model for epicormic sprout formation. Sprouting was unaffected by pruning severity except at the most severe pruning treatments. Sprout numbers and sizes were nearly constant from the control trees to trees receiving treatments that left only approximately $40 \%$ live crown (Tabs. II and III). Additional branch 
Table IV. Coefficients and fit statistics for linear mixed effects model of natural logarithm of number of sprouts per meter of pruned bole in 2002 and $2006 \ln (N+1)$, two and six growing seasons after pruning respectively, as a function of redwood crown ratio remaining immediately after pruning in 1999-2000.

\begin{tabular}{|c|c|c|c|c|c|c|c|}
\hline Model component & Data & Parameter & Coefficient & s.e. & d.f. & $t$-value & $\operatorname{Pr}>|t|$ \\
\hline \multirow[t]{4}{*}{ Fixed effects } & \multirow[t]{2}{*}{2002} & Intercept $\left(\beta_{0}\right)$ & 4.387495 & 0.390 & 10 & 11.24 & $<0.0001$ \\
\hline & & Slope $\left(\beta_{1}\right)$ & -5.631559 & 0.726 & 10 & -7.76 & $<0.0001$ \\
\hline & \multirow[t]{2}{*}{2006} & Intercept $\left(\beta_{0}\right)$ & 2.752960 & 0.357 & 8 & 7.71 & 0.0001 \\
\hline & & Slope $\left(\beta_{1}\right)$ & -3.802147 & 0.738 & 8 & -5.15 & 0.0009 \\
\hline \multirow{11}{*}{ Random effects ${ }^{1}$} & \multirow{3}{*}{2002} & & No. groups & Std.dev. & Var. & & \\
\hline & & Study site & 7 & 0.345 & 0.119 & & \\
\hline & & Treatment & 17 & 0.078 & 0.006 & & \\
\hline & \multirow{8}{*}{2006} & Clone & 130 & 0.359 & 0.129 & & \\
\hline & & Section & 157 & 0.644 & 0.415 & & \\
\hline & & Residual & - & 0.754 & 0.569 & & \\
\hline & & Study site & 7 & 0.001 & 0.000 & & \\
\hline & & Treatment & 17 & 0.270 & 0.073 & & \\
\hline & & Clone & 120 & 0.004 & 0.000 & & \\
\hline & & Section & 146 & 0.462 & 0.213 & & \\
\hline & & Residual & - & 0.844 & 0.712 & & \\
\hline \multirow[t]{2}{*}{ Model } & 2002 & \multirow{2}{*}{\multicolumn{6}{|c|}{$\begin{array}{l}n=168 ; \text { Bias }=-5.75 ; \text { RMSE }=22.6 \\
n=155 ; \text { Bias }=-3.00 ; \text { RMSE }=13.2\end{array}$}} \\
\hline & 2006 & & & & & & \\
\hline
\end{tabular}

No. groups = number of data groups for each nested parameter e.g., 17 treatments nested within 7 study sites; s.e. = standard error for coefficient; d.f. = degrees of freedom; Std.dev. = standard deviation, a measure of variation attributed to random effect parameter; Var. $=$ Std. dev squared; $n=$ number of observations; Bias = mean of prediction errors (Eq. (1)), and RMSE = square root of the average squared prediction error (Eq. (2)) for number of sprouts per meter of stem predicted using equation (4).

${ }^{1}$ Random effects entered model intercept.

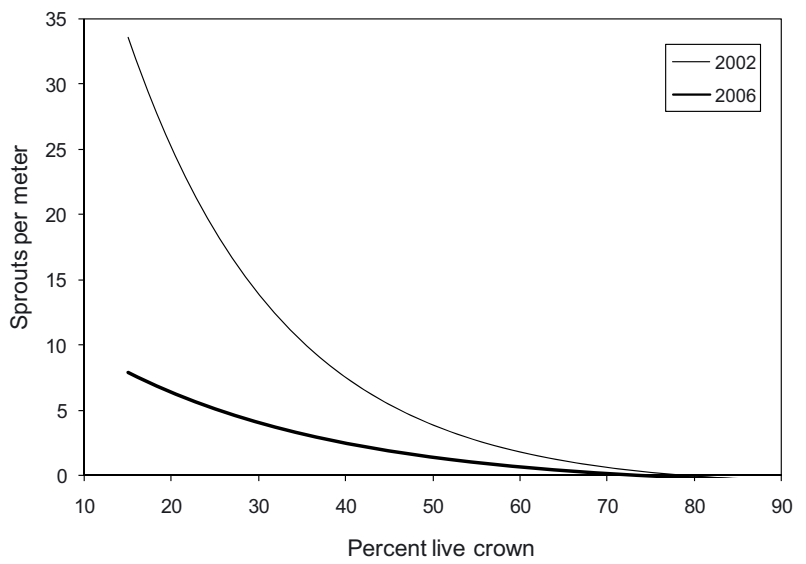

Figure 3. Relationship between percent live crown immediately after pruning coast redwood in 1999-2000 and number of sprouts per meter of pruned bole in 2002 and 2006, two and six growing seasons after pruning, respectively.

removals encouraged a strong and significant response in both size and number of epicormic sprouts. Redwood also displayed patterns of declining epicormic branch persistence with time since pruning (Fig. 3, Tab. II). Although all treatments - including the controls - resulted in some sprouting, these results suggest that pruning in young coast redwood can be effective at removing branches and enhancing wood quality without excessive epicormic sprout development if treatments leave no less than approximately $40 \%$ residual live crown. The mixed-effects model predicts that on average 2-3 sprouts per meter would remain six years after pruning to a $40 \%$ residual live crown (Fig. 3).

There is also a tendency for redwood sprouts to form more frequently in the middle and upper sections of the pruned bole (Fig. 2). Although these trends were not statistically significant, bole section was an important source of variation in the mixed effects model (Tab. IV). Dormant buds are assumed to be concentrated at the base of tree and less common further up the stem (Del Tredici, 1998). The concentration of sprouts in the middle and upper sections of the bole in this study may be due to competitive effects of vertically-oriented basal sprouts at the base or the expanding crown above (Fig. 4). Hence conditions for sprout development may be best in the middle of the pruned stem. Combined, these results suggest that scheduling thinning either several years before or after pruning could reduce light or heat reaching the pruned bole and thus reduce sprouting.

The pruning treatments tested in this study were initial "first lift" treatments applied to previously unpruned trees. Sprouting arising from any subsequent pruning treatments above the first lift - may avoid shading from basal sprouts. Presumably these sprouts would only be affected by shading from tree crowns, and decrease in frequency and persistence closer to the tree crown above. Retaining unpruned trees interspersed between pruned trees may also help control epicormic sprouting. 


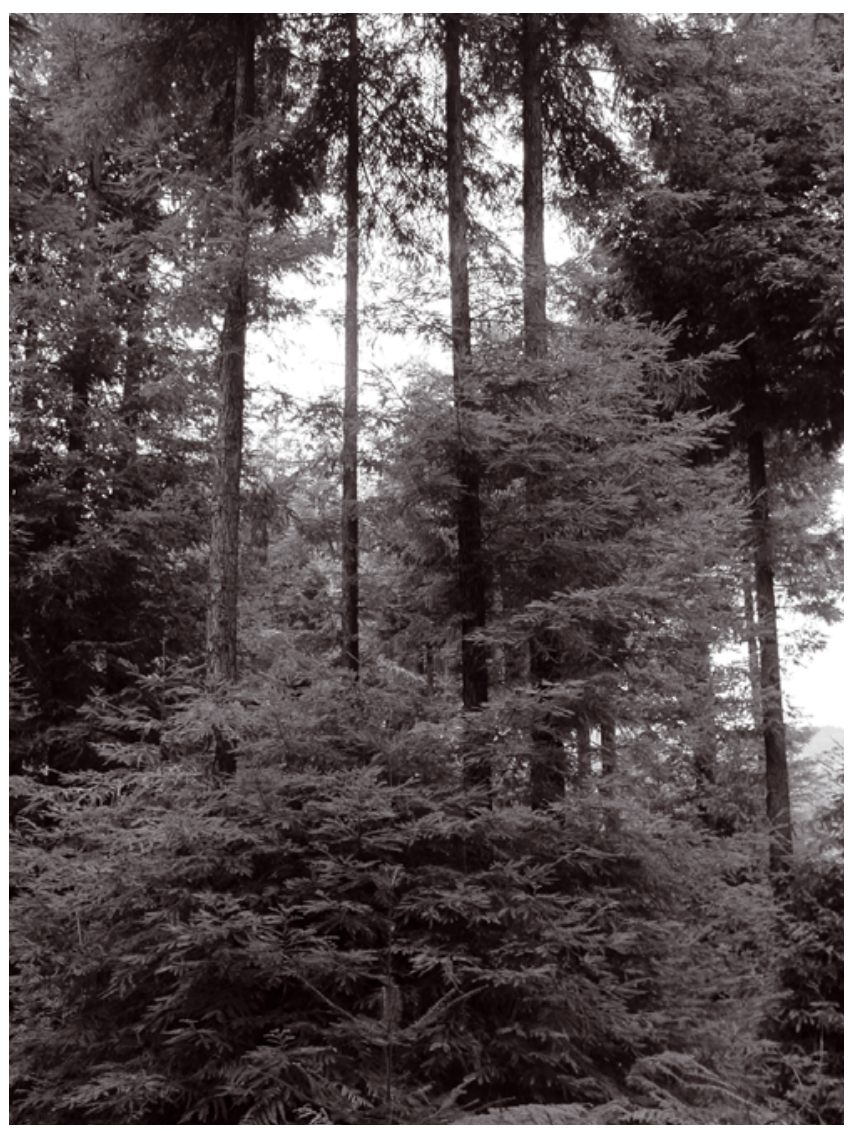

Figure 4. Redwoods five years after pruning showing development of epicormic sprouting on stems and prolific basal sprouting at base of trees.

\subsection{Genotype differences in epicormic sprouting}

Genotypic patterns of epicormic sprout development in redwood stands have important management implications. Based on the spatial patterns that indicate clones may extend at least $40 \mathrm{~m}$ (Douhovnikoff et al., 2004), it is possible that large areas may be occupied by a single clone. Pruning in these stands may result in very similar epicormic sprouting over large areas. Operational planting of select redwood clones is common on some ownerships in California and New Zealand. Selection of these clones for potential to not develop epicormic sprouts following pruning may be advantageous where wood quality objectives are important.

Our analysis of epicormic sprouting in pruned coast redwood focused on quantifying the relative effects of within and among study site variation, genetics, and bole section sampled on sprouting by comparing variances attributed to each of these random effects. The greatest identifiable source of variation in epicormic sprouting two and six years after pruning was between bole sections sampled. The second largest sources of variation were between clones and between study sites two growing seasons after pruning, but these differences had disappeared six growing seasons after pruning suggesting that study site and genetic effects may only be temporary (Tab. IV).
Only a subsample of trees were randomly selected within a treatment area for epicormic sprout study. As a result, trees that were both adjacent and clonal were not always sampled. For example, as many as nine measurement trees were noted from a single clone, but no more than 5 trees from one clone were sampled for epicormic sprouts. Additionally, many trees sampled for epicormic sprouts were the only member of their clone sampled. This analysis therefore probably underestimated the genetic effect on epicormic sprouting because sampling was designed primarily to assess interactions between pruning severity and sprouting. A sampling design focused only on trees occurring in clonal groups (greater than one tree) would have yielded stronger indications of the effect of genetics but would have probably provided less efficient parameter estimates for models of pruning severity and sprouting (than the mixed-effects models presented here).

Clones are generally located in relatively close proximity to each other. There is some potential that the genotype effect observed here is a function of a microsite interaction that affects epicormic sprouting. Alternatively, there may be a sharing of resources - and even plant hormones that affect sprouting - within the interconnections in the root system of an extended clone where the clone's available resources determine the sprouting response. The sprouting response of this clone system could therefore be environmental, not genetic although any proximate trees could be connected through root grafting. The mixed effects model variance associated with differences between genotypes was important in the 2002 model but negligible in the 2006 model. This suggests that clonal patterns may have a greater effect on initial sprout development, but sprout persistence is related to the environmental conditions that affect sprout vigor such as incident light and crown development of the host and neighboring trees. These factors may vary between sites and can be influenced by choice of pruning severity and stocking control prescriptions.

Acknowledgements: The authors are extremely grateful to Green Diamond Resource Company for providing support for this study, access to study sites, and for their cooperation in setting up the treatments. Mark Diegan, Dan Opalach, and Jim Rydelius were particularly helpful. Robert York provided a very helpful review of the manuscript. Additionally, many persons assisted in the field during the three measurements: the authors thank each of them and particularly Rolf Gersonde, Mark Spencer, and Petru Tudor Stancioiu.

\section{REFERENCES}

Auchmoody L.R., 1972. Epicormic branching: seasonal change, influence of fertilization, and frequency of occurrence in uncut stands. USDA For. Serv. Res. Pap. NE-228, 8 p.

Begin C. and Filion L., 1999. Black spruce (Picea mariana) architecture. Can. J. Bot. 77: 664-672.

Büsgen M. and Münch E., 1929. The structure and life of forest trees, English translation by T. Thomson, Chapman \& Hall, Ltd, London, $436 \mathrm{p}$.

Collier R.L. and Turnblom E.C., 2001. Epicormic branching on pruned coastal Douglas fir. West. J. Appl. For. 16: 80-86.

Cosens R.D., 1952. Epicormic branching on pruned white fir (Abies concolor). J. For. 50: 939-940. 
Crawley M.J., 2002. Statistical computing: an introduction to data analysis using S-Plus, John Wiley and Sons, Inc. Chichester, UK, 761p.

Deal R.L., Barbour R.J., McClellan M.H., and Parry D.L., 2003. Development of epicormic sprouts in Sitka spruce following thinning and pruning in southeast Alaska. For. 76: 401-412.

Del Tredici P., 1998. Lignotubers in Sequoia sempervirens: development and ecological significance. Madroño 45: 255-260.

Douhovnikoff V., Cheng A.M., and Dodd R.S., 2004. Incidences size and spatial structure of clones in second-growth stands of coast redwood Sequoia sempervirens (Cupressaceae). Am. J. Bot. 91, 1140-1146.

Eckstein E., 1974. [Dangers to success in pruning Douglas-fir.] Allgemeine Forstzeitschrift 29: 1032-1034 (in German).

Evans J., 1987. The control of epicormic branches. In: Patch D. (Ed.), Advances in practical arboriculture, Forestry Commission Bulletin 65, Her Majesty's Stationary Office, London, pp. 115-120.

Fink S., 1984. The cases of delayed or induced development of axillary buds from persisting detached meristems in conifers. Am. J. Bot. 71: $44-51$.

Harrington C.A., 1984. Factors influencing sprouting of red alder. Can. J. For. Res. 14, 357-361.

Hingston R.A., 1990. Chemical control of epicormic shoots on 4 year old Pinus radiata D. Don. Aust. For. 53: 3-6.

Insightful Corp 2005. S-Plus 7 for Windows user's guide, Insightful Corp. Seattle, WA, 654p.

Ishii H. and Ford E.D., 2001. The role of epicormic shoot production in maintaining foliage in old Pseudotsuga menziesii (Douglas-fir) trees. Can. J. Bot. 79: 251-264.
Ishii H., Ford E.D., and Dinnie C.E., 2002. The role of epicormic shoot production in maintaining foliage in old Pseudotsuga menziesii (Douglas-fir) trees II. Basal reiteration from older branch axes. Can. J. Bot. 80: 916-926.

Kerr G. and Harmer R., 2001. Production of epicormic shoots on oak (Quercus robur): effects of frequency and timing of pruning. For. 74: $467-477$.

Kozlowski T.T. and Pallardy S.G., 1997. Growth Control in Woody Plants, Academic Press, San Diego, CA, 641p.

Lange P.W., Ronde C.D., and Bredenkamp B.V., 1987. The effects of different intensities of pruning on the growth of Pinus radiata in South Africa. South African For. J. 30-36.

Littell R.C., Milliken G.A, Stroup W.W., Wolfinger R.D., and Schabenberger O., 2006. SAS for mixed models. 2nd ed., SAS Institute Inc. Cary, NC. 814 p.

O'Hara K.L., 2007. Pruning wounds and occlusion: a long-standing conundrum in forestry. J. For. 105: 131-138.

O'Hara K.L. and Valappil N.I., 2000. Epicormic sprouting of pruned western larch. Can. J. For. Res. 30: 324-328.

O'Hara K.L., York R.A., and Heald R.C., 2008. Effect of pruning severity and timing of treatment on epicormic sprout development in giant sequoia. Forestry 81: 103-110.

Stein W.I., 1955. Pruning to different heights in young Douglas-fir. J. For. 53: 352-355.

Waring K.M. and O'Hara K.L., 2005. Ten-year growth and epicormic sprouting response of western larch to pruning in western Montana. West. J. Appl. For. 20: 228-232.

Zimmermann M.H. and Brown C.L., 1971. Trees: structure and function, Springer-Verlag, New York, 336p. 